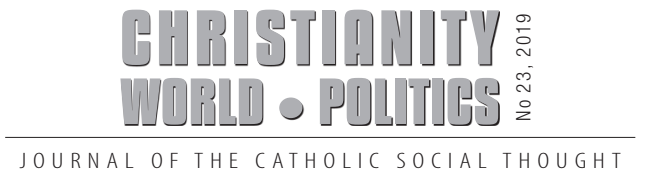

Rev. Piotr Mazurkiewicz

Cardinal Stefan Wyszyński University in Warsaw, Poland

\title{
What Should a Political Scientist Know About Religion?
}

\begin{abstract}
A political scientist will not see any reasons for becoming seriously interested in the phenomenon of religion unless he finds religion to be a lasting phenomenon in the history of civilization. The first question that needs to be answered in order to talk reasonably about the borderland between religion and politics is the issue of what religion is, and how historical religions essentially differ from one another. One may then study, for example, the political effectiveness of religious motivation. The other question is whether a functional approach to religion in the context of political science is sufficient. The author suggests that it should be replaced with a semi-substantial approach. It requires from a political scientist to understand the essence of a particular religion and the extent to which certain social consequences of religious beliefs (e.g. polygamy, religiously motivated violence, separation between religion and politics) are related to its essence, and to what extent such relationship is merely accidental.

The article also analyzes traditional areas of a political scientist's interest in religion, i.e. the relationship between the state and religious communities, religiously defined and motivated interests, and the state's policy towards religious institutions. In addition, new areas of interest are discussed, such as confessional politics in the EU, or forgiveness as a political category of current relevance and a strictly Christian origin.
\end{abstract}

Key words: religion, reconciliation, Christianity, Islam, political science

Abstrakt: Powody do poważnego zainteresowania zjawiskiem religii ze strony politologia pojawiają się dopiero $\mathrm{w}$ momencie uznania przez niego religii za trwałe zjawisko w dziejach cywilizacji. Pierwszym pytaniem na jakie trzeba odpowiedzieć, aby sensownie mówić o styku religii i polityki, jest kwestia tego, czym w ogóle jest religia i co odróżnia w sposób istotny poszczególne historyczne religie. W dalszej kolejności możemy badać np. faktyczną polityczną efektywność religijnych motywacji. Powstaje także pytanie, czy funkcjonalne podejście do religii na gruncie nauk o polityce jest wystarczające. Autor proponuje zastąpienie 
go podejściem semi-substancjalnym. Wymaga ono od politologa zaznajomienia się z treścią danej religii i próby zrozumienia na ile pewne społeczne konsekwencje konkretnej wiary religijnej (np. poligamia, przemoc motywowana religijnie, separacja religii i polityki) związane są z jej istotą, a na ile są one powiązane jednie akcydentalnie.

W tekście podjęta jest także analiza tradycyjnych obszarów zainteresowania religią ze strony politologa, tzn. relacje państwo a wspólnoty religijne, religijnie definiowane i motywowane interesy oraz polityka państwa wobec instytucji religijnych. Ponadto poruszone są nowe obszary takiego zainteresowania, jak np. polityka wyznaniowa UE, zmiana struktury demograficznej poszczególnych religii w Europie czy wreszcie przebaczenie jako istotna współcześnie kategoria politologiczna o proweniencji ściśle chrześcijańskiej.

Słowa kluczowe: religia, pojednanie, chrześcijaństwo, islam, politologia

The title question of this article is based on the assumption that a political scientist should know something about religion in the first place. This assumption seems reasonable, and rather obvious, only if we recognize that religion affects political attitudes and choices made by citizens, and that it has any future at all, i.e. that religious traditions and communities are not merely an archaic relic of premodern societies transferred into contemporary times. Once we assume that the phenomenon of religion is on the decline, and that religious people will sooner or later become extinct, just like so many other endangered species, the political scientist no longer needs to be bothered with such problems too much. He may simply limit his expert opinion to a postulate that a kind of preserves or heritage parks be established so that such groups can die and rest in peace. Jurgen Habermas once wrote:

"As long as secular citizens are convinced that religious traditions and religious communities are, as it were, archaic relics of premodern societies persisting into the present, they can understand freedom of religion only as the cultural equivalent of the conservation of species threatened with extinction. (...) Even the principle of the separation of church and state can have for them only the laicist meaning of benign indifference" [Habermas 2012: 139].

Assertions based on the assumption that the nature of all religion is not only ephemeral, but also alienating, i.e. harmful, are part of one of the main social philosophies of the Enlightenment, that is Marxism. It considers the thesis about the extinction of religion to be a scientific standpoint, while the opposite view 
is seen as a superstition. "The above claim has been proclaimed and postulated most emphatically, even 'required' in relevant circles, as a synonym of the only scientific method and, moreover, of the 'scientific worldview'. Today, such claims are no longer made with a similarly unqualified finality", John Paul II said at the Catholic University of Lublin in 1987 [John Paul II 1998: 424]. The demise of the Marxist paradigm and the role played by religion in the entire process should make scholars a little more cautious in their postulates about the social "death of God".

The failure of communism is not the only argument demonstrating the scientific error of atheism. Religion perceived from a purely sociological perspective in the global dimension is well and thriving as well. The number of persons who declare a religious affiliation both in absolute and relative terms keeps growing year to year, and forecasts for the future are - as far as people of faith are concerned rather optimistic [Pew Research Center 2016]. Europeans find it hard to realize, though, as processes occurring on the Old Continent represent an exception on a global scale and have the opposite dynamic PB: [Inglehart, Norris 2006: 322-323].

Another important reason for political scientists to become interested in religion is the actual political effect of religious motivation. Let us call to mind two events in which religion has played an essential role: the third wave of democratization [cf. Huntington 1993], and the so-called Arab Spring. In my numerous contacts with high EU officials, I looked in disbelief at their collective identification of these two phenomena. I have often heard assertions, made with much confidence, that secular authoritarian regimes in the North Africa and the Middle East are falling before our very eyes, and will most certainly be replaced with liberal democracies. A similar optimism characterized American politicians commenting on the future of Iraq shortly before the invasion of coalition forces. In both cases, that of the bankruptcy of communism and of the Arab Spring, religion was an essential factor. Different religions have different consequences in social and political life, however. It is not enough, therefore, to acknowledge that religion matters. One must know something about what effects are brought about by different religions ${ }^{1}$. Political scientists (and politicians) who display misconceptions in their political thoughts and actions about the significance of religion, or who are ignorant of the content and historical traditions of different religions, may not only be wrong in their expectations about developments in the political situation, but may actually

1 Pippa Norris and Ronald Inglehart conclude that it is impossible to compare different religions, as each of them is sui generis; nevertheless, the significance of certain elements of different religions in different cultures does yield to comparison [Inglehart, Norris 2006: 302]. 
be politically dangerous. This awareness may have been the reason for establishing a 'pôle religions' at Quai d'Orsay in 2009 (Service-Public) for the purpose of analyzing religions for the French Ministry of Foreign Affairs.

The first thesis, therefore, which a political scientist should consider is the lasting character of the phenomenon of religion. Man is a homo religiosus, he is "incurably religious". And the other is that religion influences social and political life, and that the consequences of this influence depend on the religion. Attempts at eliminating religion from social life are doomed to failure, though in the meantime they may contribute to increasing the number of martyrs in churches and religious communities. On the other hand, there is a dispute going on in societies about the quality of the sacrum that is influencing social life.

\section{What Is Religion, Anyway?}

This question seems banal enough. Not only has this term been around in our civilization for centuries, after all, but we encounter it in the media all the time on a daily basis. The difficulty, which we are not always aware of, is that our associations with this concept have developed - irrespectively of our personal attitude to religious faith - in a strictly Christian context. Georg Wilhelm Hegel, for example, considers Christianity to be the only absolute religion [Hegel 2007: vol. 2, 198]. In his comments on this view, Remi Brague says that according to Hegel, Christianity is the only religion which is nothing else but religion; or which is "pure" religion, we might say. All other religions have an admixture of something "foreign", which is not religion. There is some additional element thrown in together with the religious one. Judaism is a religion and a people, or - if you will - a religion and a morality. Islam is a religion and a legal system. Buddhism - if it is a religion at all - is also a doctrine of wisdom [Brague 2018: 40]. One may theorize, however, that Hegel, precisely in the light of his Christian experiences, defined religion so that it could only be fully satisfied by Christianity. Continuing along these lines, one might say that the definition of religion we use in Western social sciences is highly European-centered. Should a political scientist realize this, and should he understand why the word European-centered when referred to religion means something different than when it is used in the context of law or culture, for instance? Should he - if we agree with Brague's comments - know what is of a strictly religious nature in other beliefs and what is not, being merely an additional element, a "contamination" of sorts? In the former case, the imposition by the state of any restriction on religious practices could - in view of the Western definition of religion - be considered a restriction 
of the right to religious freedom; in the latter, this would no longer be the case. It seems that knowing the answer to these question matters, for example, in the context of the dispute going on in Europe about the right to wear "ostentatious" religious symbols, such as e.g. a burqa, a chador, or a hijab. While such disputes may be approached on the grounds of functionalism, i.e. by looking for a solution which leads to ensuring social peace without going into the essence of the dispute, the question is whether such peace would last, and whether we are not dealing with apparent functionalism in a case like this, i.e. a substantial approach which has not been explicitly articulated. A political scientist always has some concept of religion in the back of his head, possibly without even realizing where this concept came from, taking it for granted as the only possible and obvious one.

A good illustration of the paradox of functionalism when applied to religion is the example provided by Robert Spaemann. He notes that the state's positive attitude to religion often depends on the extent to which it helps the state achieve certain important non-religious objectives. Religion is therefore allowed to exist in the public sphere, only to the extent, however, that it properly fulfills the secular function it is assigned. It is for this reason that even secular France has not abandoned the idea of military chaplains, or of inviting bishops or imams to marches against violence organized after terrorist attacks. The point is often simply about charitable or educational goals, however. As an example of the functional approach, Spaemann describes the reaction to the claim that zen meditation is important, because policemen who practice it are better snipers. This claim may be true, yet the question is open as to how this would be relevant to an individual who were to engage in certain religious practices in order to improve their "efficiency" at work. Should police officers be ordered to "convert" to zen and practice meditation? If we perceive religion and religious communities in terms of the functions they perform, we risk not only running into a host of misunderstandings, but also popularizing an instrumental approach to these religions and communities. Functionalism treats the society as a black box into which certain inputs are introduced, to be then processed in accordance with an algorithm known to the operators, in order to receive a desired output. No one is interested in what actually is inside the black box. An algorithm which does not take into account the nature of the religious factor and the essential differences between various religions may be dangerously unreliable, however. Moreover, a purely functional approach could be perceived by the religious communities concerned as disrespectful, if not - to use religious terminology - blasphemous. Let us recall the dispute going on in Brussels over what the 
"specific contribution" means in Article 17 of the Treaty on the Functioning of the EU. I will leave the question open whether politicians (political scientists) should be allowed to approach the religious feelings of citizens in a disdainful manner, even if inadvertently or due to ignorance. The point is not so much to provide a particular answer here, but to pose a particular question.

What can be proposed instead of functionalism? Reflecting on the possibility of an inter-religious dialogue between Christianity and Islam, Marcelo Pera points out that strictly speaking such a dialogue is impossible. Both religions have their holy scriptures which they believe to have been revealed by God, and any attempt at "negotiating" or "adjusting' their content to account for that of another religion would presume relativism. Each of these religions, as has already been mentioned, causes different cultural effects, however, and a dispute over which of them are more or less desirable in view of the common good does not have to refer to which of them is considered "true" or "false" at all. In this context, Pera introduces the concept of "empirical patrimony", which in Europe is strictly Christian in character, and asks whether "the cultural consequences of Islam are compatible with the moral patrimony of humankind? With democracy? With the Charter of Human Rights?" [Pera 2008: 132-133]. In other words, he suggests a discussion concerning the extent to which polygamy, violence, lack of separation between religion and politics, etc., are essentially related to Islam as a religion, and to what extent their relationship is accidental. This approach may be described as semi-substantial. In the context discussed here, it means that a politician who takes decisions (or a political scientist who offers his suggestions) should be aware of the course of such debates, and - if they are conclusive - of their results. In fact, it appears that we actually follow just such or similar guidelines; in other words, we do not appoint religious philistines as diplomats, and we do not rely in foreign policy on experts who are dilettantes as regards the religious context of decisions to be taken. The point is, to a large extent, that this should be done in an informed way. Especially that - as Samuel Huntington as well as others have pointed out - religion represents the foundations of every civilization, even though differences between civilizations cannot be reduced to those due to religion [cf. Huntington 1996].

What is religion, then? When looking at the Latin etymology of the term "religion", we will notice that there are two aspects to it. Cicero derives the word religio from relegare, which means: to regather, to reconsider, to reread, to repeat, to rerun. Consequently, religiosi are people who try to carefully observe and repeat 
all that is related to gods ${ }^{2}$. Understood this way, religion is first of all a collection of beliefs and practices related to gods, peculiar to a particular nation and passed on by tradition. Re-reading involves the use of reason, whence religio may also be considered as the opposite of superstitio - superstition ${ }^{3}$. The religious need inherent to human nature means, as has been pointed out by Alasdair MacIntyre, that man always - even if he considers himself to be an agnostic or an atheist - professes some religion or superstition. Consequently - as should be emphasized - the emancipatory power of religion with respect to superstition is always liberating ${ }^{4}$. What should be stressed in the very definition of religion is its relation to reason. Whether we are in fact dealing with a mere superstitio or with religion depends on whether it is a faith which tries to understand, or a faith which is merely fideistic. Religion, therefore - considered in the European context - is not afraid of properly used reason; quite on the contrary, it opens reason to the fullness of truth about reality, it expands its cognitive horizon. If religion were banned from the university, or if questions about the relationship between a particular religion and violence were to be prohibited, as Benedict XVI emphasized at the University of Regensburg, reason, and consequently political science, would become helpless in the face of attempts at abusing religion [Benedict XVI 2017: 27-53].

Early Christianity related the word "religion" more often to re-ligare, to re-connect, meaning, firstly, the relationship between man and God (rather than tradition), and, secondly, the relationship between believers ${ }^{5}$. Religion, therefore, is based on

2 "Such as heedfully repeated and, as it were, "regathered" (relegerent) everything that formed a part of divine worship, were named religiosus from relegere. (...) In this way (...) the word religious (...) became the designation of (...) an excellence". [Cicero, II,28].

3 Cicero links superstitio to an ,inane fear of gods" (timor inanis deorum) [Cicero, I, 117]. Over time, the word began to mean rites hostile to Rome, such as, for example, Gallic rites. Also Christianity was initially referred to by this word. In 379, heretic Christian dogmas were called perversa superstitio. Summing up the evolution of conceptual frameworks which survived the demise of the Western Empire, Bruno Dumézil says that religions were most often defined as the whole of cults allowed by civil law. They were divided into two groups: religio par excellence present in the state's institutions, and religiones licitae, meaning cults which, while permitted, did not enjoy a legal status equal to that of the state religion. Superstitio, on the other hand, began to mean all beliefs prohibited by law [Dumézil 2008: 49-60].

4 "Part of the gift of Christian faith is to enable us to identify accurately where the line between faith and reason is to be drawn, something that cannot be done from the standpoint of reason, but only from that of faith. Reason therefore needs Christian faith, if it is to do its own work well. Reason without Christian faith is always reason informed by some other faith, characteristically an unacknowledged faith, one that renders its adherents liable to error" [MacIntyre 2013: 211].

5 "Man is bound to God by the ties of piety, whence religion itself receives its name". Lactantius, Epitome of the divine isntitutes, LXIX, in: Fletcher W. (ed.), The works of Lactantius, Edinburgh: T. \& T. Clark, vol. II, p. 157. 
a personal relationship between man and God which is realized in the community of the Church. The risen Christ is the only Mediator between the Father and people. At the same time, he breaks down the wall of hostility that kept mankind apart, making two kinds of people into one [cf. Ephesians 2:14]. There is neither Jew nor Gentile, neither slave nor free, nor is there male and female [cf. Galatians 3:28]. All of these features become insignificant compared to the fact God has adopted man and made him his foster child. This way of substantiating the oneness of humankind is specific to Christianity. Thus, religion has two dimensions: the vertical and the horizontal one. It is fulfilled through the implementation of two commandments of love - of God and of one's neighbors. As a consequence of this approach, Christianity claims that religion is not merely a private matter, reducible to acts of cult performed within the four walls of one's home. Religion - according to Christians - is a public matter, and any attempts at denying or restricting the right to confess and practice one's faith in the public sphere are always felt as a violation of the right to religious freedom, which political scientists must never forget. Religion cannot be reduced, therefore, to the experience of some form of spirituality.

\section{Traditional Areas of Political Interest in Religion}

Petr Fiala offers a rather apt summary of the three traditional areas where religion and politics come into contact. Firstly, there is the relationship between the state and religious communities (polity). Secondly, there are religiously defined and motivated interests (politics). And thirdly, there is the religious policy of the state [Fiala 2016: 133-137]. The claim he makes, however, that the force of the public influence of religious institutions, including the Catholic Church, and of Christian political parties has declined so much that disputes in these areas no longer matter, is arguable. It seems that literature on the subject, particularly on the model of the relationship between the state and the Church in the Western world, is abundant enough, and there is no need to dwell upon this issue here. Nevertheless, even recently we have witnessed significant developments, e.g. in Norway, Sweden, Italy, Spain or Malta, not to mention Central and Eastern Europe, where legal regulations in this area have changed. Admittedly, these changes fit within the three models mentioned above, and in this sense the saying nihil novi sub sole is true. As regards the second area, it should be said that the situation is very dynamic. A debate has swept through Europe recently about what the "C" means in the name of Christian democracy, and what it changes in its politics. Let us call to mind that Christian democracy in Italy has fallen apart, and at the same time the "C" has returned to the official name of the European People's Party. 
Do "C" parties really represent any interests of the Church? This question entails the implicit view that the Church is, in fact, simply one of many interest groups, and consequently its treatment as a large lobby organization is quite reasonable. What interests would this be about? Material? Ideological ones? A striving for political power in disguise, or an ideological fight for the souls?

There are parties in Europe, however, which - while not representing the Church make explicit references to Christianity in their very names. Their policies, as has been mentioned, have inspired a discussion over the meaning of the " $\mathrm{C}$ " in the names of political parties. One of the theses proposed in this context was that a majority of the most problematic regulations concerning the protection of life, marriage and family would probably never have been approved in Europe, if Christian democrats had not adopted a strategy of "lesser evil". The main example, as has been stressed by Vladimir Palko, is the Italian Act No. 194 concerning abortion, which is the only pro-abortion law in the world signed exclusively by Catholic politicians (Giulio Andreotti, Tina Anselmi, Francesco Bonifacio, Tommaso Morlino, Filippo Pandolfi) [Palko 2010; [Lohmann 2011: 161-171]. Twenty five years later, Giulio Andreotti said: "Today, I would rather resign than sign that Act” (Palko). Unfortunately, those C-parties which are large enough to aspire to seizing power, still employ the same strategy. The problem is not a new one. Max Weber once wrote: "Some parties, and notably those in America since the disappearance of the old conflicts about the interpretation of the constitution, have become simply parties of position-seekers [Stellenjägerparteien] which change their substantive programme according to the chances of winning votes" [cf. Weber 1994: 321]. On the one hand, contemporary C-parties prefer to avoid axiological disputes rather than risk internal conflicts which could result in a break-up of the party itself ${ }^{6}$. On the other hand, when judging their politics by the fruit, one has the impression that some of them are infiltrated by political opponents. Petr Fiala says that due to "an erosion of the Christian political subculture, major Christian parties have gradually (...) transformed into conservative-liberal or conservative-social ones. Some have adopted the model of 'catch-all parties', others have become oriented towards certain social groups, or particular regions" [Fiala 2016: 135].

${ }_{6}$ Current axiological disputes stem from different anthropological visions. One can say that there exists an anthropological dispute between, on the one hand, Christian vision of a man and, on the other, a vision developed in the Enlightenment; between - to recall typology proposed by Michał Gierycz - „constrained” and „unconstrained” anthropology [Gierycz 2017]. Anthropological distinction should not be identified with political fractions. Also among members of, so called, „C-parties” there are proponents of those both anthitetical pre-judgements about a dignity of a man. 
The question is whether Christians still need nominal C-parties? If so, how can they make the "C" mean more than an aesthetic embellishment? One of the measures that have been proposed is to create small Christian groups within large political parties. This could help their members overcome a sense of isolation, introduce Christian reflection into the main stream of the political debate, and ensure that the Christian viewpoint is presented explicitly. Certainly, there are still enough committed Christians within these parties to make such minority groups possible; it would be a major overstatement, however, to say that C-parties exist today to defend some interests of the Church.

The third area certainly includes the debates going on in the West, already mentioned above, as well as the accompanying legal measures prohibiting the wearing in public places, or only inside public buildings, of religious headwear or clothing (chadors, niqabs, burqas, burqinis, or turbans), or - more broadly - "ostentatious religious symbols". I believe this area also includes the French discussion initiated by President Sarkozy concerning laïcité positive. It is also worth calling to mind that we are witnessing major discrepancies in the approach of political culture to the presence of religion in the public sphere. I do not only mean the difference between European confessional states, religiously neutral states, and secular France. In the dispute over the presence of a cross in an Italian school initiated by a citizen of Finland living in Italy, which was finally resolved in the second instance by the European Court of Human Rights in Strasburg, the case, as it turned out, was merely about legally defending Italian cultural tradition [European Court of Human Rights 2011]. And so, the cross remained because such is the law of the country. In a somewhat similar dispute over the cross on the John Paul II monument in Ploermel, France, the court ordered that the cross be removed from public space, and the citizens of the town complied by moving the monument a dozen or so meters over to a private plot of land.

\section{Res novae in Religion and Politics}

Res novae have certainly appeared in the activities of international organizations, such as the United Nations and similar regional organizations, as well as the European Union. In the former case, there have been repeated attempts at denying the Holy See the status of a member or permanent observer, and replacing it with the status of a large non-governmental organization.

In the latter case, the situation is more complicated, as this international organization seems to have a specific confessional agenda, which touches, be it in a new 
form, upon the third area mentioned by Fiala. We have witnessed animated discussions about references to Christianity in the preamble to the EU Charter of Fundamental Rights, and the EU Constitutional Treaty. We have a number of EU directives and regulations which directly or indirectly affect the functioning of churches and religious organizations, including their legal status in the Member States [Mazurkiewicz, Ptaszek, Młyńczyk 2019]. Finally, there is Article 17 TFEU which makes it mandatory for EU institutions to dialogue with churches and religious organizations. The density of mutual relationships between EU institutions and churches and religious organizations keeps increasing, but at the same time a tendency is becoming more and more visible in EU politics to change these religions through efforts from the inside. To illustrate this issue, let us call to mind Regulation (EU) 2016/679 of the European Parliament and of the Council of 27 April 2016 on the protection of natural persons with regard to the processing of personal data and on the free movement of such data [Regulation (EU) 2016/679 of the European Parliament and of the Council]. While Article 91(1) allows churches and religious organizations to maintain their autonomous system of personal data protection, it does so at the cost of transferring into the system of canon law the model of protection provided for in EU regulations. This way, politicians define the standards of data protection in churches. There is an analogy here also with the debate concerning sexual abuse in churches. Under the influence of political and media pressure, churches often assume not only the sensitivity, but also the terminology and standards for protecting persons, particularly minors. And this is not a criticism of such practices, but merely a statement of their existence.

In order to show another innovative element in the relationship between religion and politics in Europe, we will make a small thought experiment. Let us take a photograph taken in Germany in May 2018. It presents the inside of a Roman basilica built under Emperor Constantine, currently used by the Protestant church. In the center of the photograph there is an altar with the words: „1818-2018. Karl Marx - Trier"' Behind the altar, instead of a pastor who usually stands there while celebrating liturgy, we can see Jean-Claude Juncker, President of the European Commission, addressing the audience. A number of naïve questions come to

7 In a speech in honor of Marx, Junker said: „Karl Marx was a philosopher, whose thought into the future had creative aspirations. (...) Today he stands for things which he is not responsible for and which he didn't cause, because many of the things he wrote down were redrafted into the opposite. (...) He is the main founder of Marxism, the founder of Marxist political parties and the creator of international communism, and the greatest thinker of modern times" [Churm 2018]; Complete recording of the President's speech: J.-C. Juncker, 2018. 
mind: Why is the meeting being held in a church? Is this a service, or a political meeting? Has Juncker changed his confession and become a Protestant pastor? Or the other way round, perhaps, has a pastor become the head of the European Commission? Has the Church changed its approach to communism and no longer treats it as a synonym of godlessness? Is the European People's Party a continuator of the Communist International, and the European Union a successor of the Soviet Union? I am not sure if these questions are serious or not, but the picture certainly represents a meeting point of two worlds: that of religion and politics, where the former hospitably offers its space, and the latter takes over the teaching mission.

Another area in which political decisions very clearly influence the phenomenon of religion in Europe is the migration policy, both at the level of national states and that of the Union. Since for some time now the inflow of immigrants to Europe has been clearly dominated by the confessors of a single, non-European religion, decisions about the preferred directions from which Europe will receive immigrants and about the number of immigrants to be received represent a major factor influencing the religious demographics of the Old Continent. We may say that it is politicians who largely determine future disproportions between various confessions and religions in Europe. This is very much unlike the confessional policy employed in the past by communist countries; it seems, however, that calling it a confessional policy is most reasonable. In both cases, knowledge about religions and their specific contribution - to cite TFEU - to social and political life is a must for a political scientist, including the ability to distinguish between the consequences of this contribution depending on whether the skyline is dominated by the steeples of Gothic cathedrals or by minarets.

When talking about new things, one cannot fail to mention the Western discussion about religion and violence. The fundamental question in the face of the fear of terrorism spreading in Western civilizations is whether resorting to violence is an integral part of a particular religion, or whether it is only accidental, meaning that terrorists are acting on their own account, without having the religious legitimation of their community? From time to time, Islam is placed in the center of the public controversy. This was the case after the address of Pope Benedict XVI at the University of Regensburg in 2006. Few people seem to have registered the fact that it was entitled: "Faith, Reason and the University" [Benedict XVI 2006]. It was not the Pope's intention to cause a dispute with Muslims, but to propose a critique of modern reason from within. It was not an attempt - as the Pope made clear to turn our clocks back to pre-Enlightenment time, but a moment of necessary 
reflection on modern reason so that it is not entirely defenseless in the face of contemporary challenges. As Lee Harris points out in his comments on the Pope's address, when speaking at the University hall, Benedict XVII was not lecturing from the position of the Head of the Church who "knows all the answers", but from that of a sage who - like Socrates - "knows all the questions" [Harris 2006]. According to Harris, the Pope believes that the concept of rationality characteristic of the Western world is being attacked nowadays from two different sides: that of Islamic fundamentalism, and that of contemporary Western intellectuals who, reducing rationality to that which can be measured using the methods of empirical sciences, a mixture of mathematics and empiricism, narrow it down considerably compared to the Greek concept. Modern reason, the Pope argues, by excluding the issues of religion and ethics from the scope of its research interests, and transferring them to the area of choices which are entirely private, subjective and "irrational" - from the point of view of this narrowed-down concept of rationality - is unable to pass any value-judgments on different religions even as regards their attitude to violence. Consequently, it cannot participate in a discussion about which of the two religions: Christianity or Islam, is more rational and whether, for example, the thirst for human blood is a reflection or the opposite of divine nature. The very survival of reason depends on its ability to answer these questions. It may only function within a community of rational people, within a culture whose members agree that violence is not a legitimate method of influencing human minds. If reason has nothing to say about pathologies of religion, it may perhaps still remain modern reason, but it is far from certain whether it will be able to survive outside of the "culture of reason" (Johann Herder) at all. Consequently, it seems justified that two postulates be addressed to modern reason: an ethical and a religious one. The ethical postulate is: "Do whatever is possible to create a community of reasonable men who abstain from violence, and who prefer to use reason" [Harris 2006: 81]. In our native tradition, this postulate used to be expressed in its Latin version as plus ratio quam vis. And the religious postulate is: "If you are given a choice between religions, always prefer the religion that is most conducive to creating a community of reasonable men, even if you don't believe in it yourself" [ibid.]. It appears that these two conclusions of the Pope's address in Regensburg, so loudly protested against in the Muslim world, should not outrage people of science, in particular political scientists, in our secularized Western world.

\section{Religion and European Demographics}

For the past several decades, Europe has been experiencing a demographic crisis. It is not often acknowledged that this crisis also has a religious dimension. In 
2015, Muslims were the youngest religious group in Europe (with the average age of 33 years, compared to 43 years among Christians). In 2010-2015, in none of the European countries the number of deaths among Muslims exceeded the number of births, which was the case in 24 out of the 42 countries among Christians. In result, the birthrate among Muslims in Europe was 2290000 persons, compared to a negative birthrate of -5640000 among Christians. The respective forecasts for 2055-2060 are 1480000 persons for Muslims and -12 320000 persons for Christians. This is also related to a religiously differentiated fertility rate. On the global scale, it is decidedly higher in the case of women who are believers than in the case of women who do not declare any religious affiliation (2.5 and 1.6, respectively), which has been pointed out already by Ronald Inglehart [cf. Inglehart, Norris 2011]. The situation in Europe is similar, even though the respective fertility rates and differences between religions are markedly smaller (1.7 and 1.5 , respectively $)^{8}$. On the global scale, the total fertility rate is 3.2 among Muslim women, 2.7 among Christian women, and 1.7 among women who do not declare any religious affiliation ${ }^{9}$. According to Eurostat, the total fertility rate for the entire EU in 2017 was 1.59 [Eurostat 2018].

Next to fertility rates, the second major factor affecting the confessional demographics of Europe is migration, already mentioned above. According to Pew Research Center data, it is expected that the Muslim community will reach $8.45 \%$ of the total population of Europe without migration, and $10.2 \%$ including migration. The expected influence of migration on the confessional structure is higher in Europe than in the case of other continents. In result, it may be expected that such European countries as Great Britain, France, the Republic of Macedonia, Bosna and Herzegovina, or Holland, where Christians represent more than half of the population today, will no longer be countries dominated by Christians. In the case of Great Britain, Christians will still remain the largest religious group, representing $45.5 \%$ of the society. In the case of Bosna and Herzegovina, the largest group will be Muslims (56.2\% and 49.4\%, respectively). And in the case of France and Holland, the largest group will be those who do not declare any religious affiliation (44.1\% and $49.1 \%$, respectively). We may thus expect a "victory" of Islam in the Balkan states, of atheism in France and Holland, and of Christianity in Central Europe. Actual changes in the religious demographic structure of Europe will depend on the decisions made by politicians, however. For example, Pew Research

\footnotetext{
8 Forecasts for the years 2015-2020.

9 Data for the years 2010-2015.
} 
Centre has prepared three different scenarios of future developments depending on the migration policy adopted in Europe [Pew Research Center 2017]. And it is worth noting that in addition to making decisions about the desired scenario, politicians and political scientists will also be faced with the necessity to take into account the sense of "ontological threat" and the social feelings accompanying this phenomenon ${ }^{10}$. Its literary expressions, such as those by Michel Houellebecq, are not merely an effect of artistic imagination [Houellebecq 2015].

\section{Secularization and Short-Sightedness}

In a travesty of a saying by Winston Churchill, Rémi Brague says that democracy is the best regime from the standpoint of those who represent a democratic community at the moment. If it stays for good, however, in the long run it will lead to the extinction of mankind [Brague 2014: 304]. Brague is referring here to Alexis de Tocqueville who believed that religion instills in man a general habit of thinking about distant future (longanimitas) with the awareness that one day man will have to stand naked before the Judge, "out of [where] two roads lead: one to the islands of the blest and the other to Tartarus" [Plato 1994: 116]. "But in proportion as the light of faith grows dim", writes Tocqueville, "the range of man's sight is circumscribed, as if the end and aim of human actions appeared every day to be more within his reach. When men have once allowed themselves to think no more of what is to befall them after life, they readily lapse into that complete and brutal indifference to futurity, which is but too conformable to some propensities of mankind. As soon as they have lost the habit of placing their chief hopes upon remote events, they naturally seek to gratify without delay their smallest desires; and no sooner do they despair of living forever, than they are disposed to act as if they were to exist but for a single day." [Tocqueville 2002: 617]. Short-sightedness is, so to say, inherent to the nature of a secular democratic state. The community of those living at present is not naturally interested in making laws beneficial to those who have not come into this world yet. Man forgets the observation, made already by Aristotle, that "statesmanship does not create human beings but having received them from nature makes use of them" [Aristotle: 1258a]. In other words, children are not born spontaneously. If we are not consciously committed to giving life to a new generation, children will simply not be born in numbers sufficient to prolong the existence of a democratic community. The contraceptive pill - in this perspective - may prove to be a greater threat to democracy than the atomic bomb [Brague 2014: 299].

10 The debate on this subject has been aptly summarized by Ivan Krastev [Krastev 2017] or Monika Gabriela Bartoszewicz [Bartoszewicz 2018]. 
Instead of being properly concerned about those who are, as yet, "absent", we are witnessing a waning sense of intergenerational solidarity, and an increasing popularity of various versions of neo-Malthusianism. The dramatic decline in birth rates in Europe was pointed out by John Paul II, who linked it closely to secularization and the disappearance of hope ("extinguishing hope") in the Old Continent [John Paul II 2003: 7-10, 12-16]. Similar comments, though, naturally, not in the context of a possible "demographic death of Europe", were made by Immanuel Kant: "Hence then also morality is not actually the doctrine of how we make ourselves happy, but rather of how we make ourselves worthy of happiness. Only then, upon the advent of religion, does the hope arise of someday participating in happiness in that measure as we were considered to be not unworthy of it. (...) [O]nly with religion does the hope for happiness first arise" [Kant 2012: 167-168].

It seems that the knowledge about where societies are to find the hope they need to survive in the historical dimension may also be useful from the standpoint of a political scientist.

\section{Religion and Forgiveness}

The only way to establishing peace in a secularized world is forgiveness - John Paul II wrote soon after the attack on the World Trade Center [John Paul II 2001: 4, 63]. Forgiveness as an absolute moral obligation resulting from the commandment to love enemies is not a secular "good", however, but is a novum brought into the history of civilization by Christianity ${ }^{11}$. The possibility of establishing peace in a secularized world depends, therefore, on the ability to forgive whose source is a very concrete religion. In other words, neither Paul VI in the ecumenical context, nor the Polish bishops in their letter to German bishops, would have used the Horatian formula, changing its original sense entirely, if it had not been for their faith in and knowledge of the Gospel ${ }^{12}$.

John Paul II was aware of the novelty which Christian forgiveness had brought into the history of humankind.

Forgiveness given and received enables a new kind of relationship among people, breaking the spiral of hatred and revenge and shattering the chains of evil which bind the hearts of those in conflict with

11 More on forgiveness: see Mazurkiewicz 2007; Mazurkiewicz 2006; Mazurkiewicz 2016.

12 It referred initially to the diversity of literary genres [Mazurkiewicz 2001: 306-307]. 
one another. (...) In proclaiming forgiveness and love of enemies, the Church is aware of adding to the spiritual heritage of all humanity a new mode of human relationships; an arduous mode, to be sure, but one that is also rich in hope. [John Paul II 2001: 4, 63].

The obligation to forgive is related directly to the evangelical commandment of the love of enemies: „But I tell you, love your enemies and pray for those who persecute you, that you may be children of your Father in heaven. He causes his sun to rise on the evil and the good, and sends rain on the righteous and the unrighteous" [Mt 5,44-45]. When commenting on this text, Saint Augustine says that to fulfill this commandment, one must desire to make enemies into one's friends, which is possible through forgiveness ${ }^{13}$.

\begin{abstract}
"An inner conversion is required if this step is to be taken", John Paul II writes, "the courage to be humbly obedient to Jesus' command is needed. His word leaves no doubt: not only those who provoke hostility but also those who are its victim must seek reconciliation [cf. Mt 5:23-24]. Christians must make peace even when they feel that they are victims of those who have struck and hurt them unjustly. This was how the Lord himself acted. [John Paul II, 2001: 4, 63].
\end{abstract}

In today's world, the moral commandment to forgive and strive towards reconciliation also has an institutional dimension, for example in the actions of international institutions. World peace will not be the work of any bureaucracy, even the most efficient one, however. "[T]he fate of peace depends first of all on finding a solidarity of hearts. And this requires (...) the courage to forgive" [John Paul II 1994: 5, 13-14]. „Only to the degree that an ethics and a culture of forgiveness prevail can we hope for a "politics" of forgiveness, expressed in society's attitudes and laws, so that through them justice takes on a more human character" [John Paul II 2002: 8]. In other words, just as forgiveness precedes the establishment of true peace, so ethics and culture, and religion above all, precede politics. The history of mankind depends on the contribution made by religion, culture and ethics into social life. An awareness of these relationships may be useful also to those involved in political studies.

13 „Love your enemies, desiring them for brothers; love your enemies, calling them into your fellowship. For so loved he who as he hung upon the Cross said, 'Father, forgive them, for they know not what they do' [Luke 23:43]" [Augustine 1955: 266]. 
I have taken the liberty to sketch out just a few aspects of the relationship between religion and politics, a few pictures which - or so I believe - a political scientist should take into account in political analyses, without becoming in the least a theologian, and with the awareness that his studies belong to the domain of political science rather than theology. Can political studies be carried out today without this knowledge? They certainly can, since many authors do just that; at least some of their studies are not thorough enough, however, to be not only intellectually interesting, but also safe for the societies they refer to.

\section{Bibliography}

Aristotle, Politics, https://oll.libertyfund.org/titles/aristotle-the-politics-vol-1--5/simple. Augustin, Saint (1955), Augustine: Later Works, Westminster Press, Philadelphia. Bartoszewicz M.G. (2018), Festung Europa, Ośrodek Myśli Politycznej, Kraków.

Benedict XVI (2006), Faith, Reason and the University. Memories and Reflections, Aula Magna of the University of Regensburg, 12.09.2006, http://www. vatican.va/holy_father/benedict_xvi/speeches/2006/september/documents/ hf_ben-xvi_spe_20060912_university-regensburg_en.html.

Benedict XVI (2017), Poznanie prawdy. Wykłady papieskie, Wydawnictwo WAM, Kraków. Brague R. (2014), Modérément moderne, Flammarion, Paris.

Brague R. (2018), Sur la religion, Flammarion, Paris.

Churm P.A. (2018), Juncker opens exhibition to Karl Marx, http://www.euronews. com/2018/05/04/juncker-opens-exhibition-to-karl-marx.

Cicero, De natura deorum, http://www.thelatinlibrary.com/cicero/nd1.shtml\#117.

Dumézil B. (2008), Chrześcijańskie korzenie Europy, Wydawnictwo Marek Derewiecki, Kęty.

European Court of Human Rights (2011), Arrêt de Grande Chambre Lautsi et autres c. Italie 18.03.2011, https://hudoc.echr.coe.int/fre-press\#\{《fulltext»:[«lautsi»]\}.

Eurostat (2018), Total fertility rate, https://ec.europa.eu/eurostat/tgm/table.do?tab=table\& plugin $=1 \&$ language $=$ en $\&$ p code $=$ tps 00199 .

Fiala P. (2016), Laboratorium sekularyzacji. Kościół i religia w społeczeństwie niereligijnym, Ośrodek Myśli Politycznej, Kraków.

Gierycz M. (2017), Europejski spór o człowieka. Studium z antropologii polityczej, Wyd. Naukowe UKSW, Warszawa.

Habermas J. (2008), Between Naturalism and Religion, Polity Press, Cambridge.

Harris L. (2006), Socrates or Muhammad? Joseph Ratzinger on the destiny of reason, 10/02/2006, Volume 012, Issue 03, http://www.weeklystandard.com/Content/Public/ Articles/000/000/012/736fyrpi.asp. 
Hegel G.W.F. (2007), Wykłady z filozofii religii, Wydawnictwo Naukowe PWN, Warszawa Houellebecq M. (2015), Submission, Farrar, Straus and Giroux, New York.

Huntington S.P. (1993), The Third Wave. Democratization in the Late Twentieth Century, University of Oklahoma Press, Norman.

Huntington S.P. (1996), The Clash of Civilizations and the Remaking of World Order, Simon \& Schuster, New York.

Inglehart R., Norris P. (2011), Sacred and Secular: Religion and Politics Worldwide, Cambridge University Press, New York.

Kłoczowski J.A. (2004), Religia, in: B. Szlachta (ed.), Słownik społeczny, Wydawnictwo WAM.

John Paul II (1988), Wiara i kultura, Redakcja Wydawnictw KUL, Rzym - Lublin.

John Paul II (1994), Do prezydenta Republiki Bośni i Hercegowiny, L'Osservatore Romano Polish edition, 11(167).

John Paul II (2001), Message for Lent, https://w2.vatican.va/content/john-paul-ii/en/ messages/lent/documents/hf_jp-ii_mes_20010206_lent-2001.html (17.06.2019).

John Paul II (2002), No Peace Without Justice, No Justice Without Forgiveness. Message For the Celebration of the World Day of Peace, http://w2.vatican.va/content/john-paul-ii/ en/messages/peace/documents/hf_jp-ii_mes_20011211_xxxv-world-day-for-peace. html (17.06.2019).

John Paul II (2003), Ecclesia in Europa, Wydawnictwo M, Kraków.

Juncker J.-C. (2018), https://ec.europa.eu/eurostat/tgm/table.do?tab=table\&plugin=1\& language $=$ en\&pcode $=$ tps00199 (17.06.2019).

Kant I. (2012), The Critique of Practical Reason, trans. by Philip McPherson Rudisill https://kantwesley.com/Kant/CritiqueOfPracticalReason.pdf (17.06.2019).

Krastev I. (2017), After Europe, University Pennsylvania Press.

Lactantius, Epitome of the divine institutes, LXIX, in: Fletcher W. (ed.), The works of Lactantius, Edinburgh: T. \& T. Clark, vol. II, p. 157, https://archive.org/details/ theworksoflactan00lactuoft/page/n9 (24.05.2019).

Lohmann M. (2011), Gdzie jest „C” w CDU?, Z Martinem Lohmannem rozmawia Stefan Sękowski, Fronda 58.

MacIntyre A. (2011), God, Philosophy, Universities. A Selective History of the Catholic Philosophical Tradition, Rowman \& Littlefield Publishers, Inc., Lanham, Maryland.

Mazurkiewicz P. (2001), Przemoc w polityce, Ossolineum, Wrocław.

Mazurkiewicz P. (2006), Przebaczenie i pojednanie, Chrześcijaństwo - Świat - Polityka. Zeszyty Społecznej Myśli Kościoła 1 (1) 2006, s. 7-32.

Mazurkiewicz P. (2007), Vergebung und Gerechtigkeit als Stützpfeiler des Friedens, Christentum - Welt - Politik. Hefte zum Gesellschaftlichen Nachdenken aus Christlicher Verantwortung 1/ (1) 2007, s. 7-26.

Mazurkiewicz P. (2016), Przebaczenie czy miłosierdzie? Wokół potrzeby pojednania w polityce, Warszawskie Studia Teologiczne, XXIX/3/2016, s. 119-131.

Mazurkiewicz P., Ptaszek R.T., Młyńczyk Ł. (2019), Polityka wyznaniowa. Perspektywa Unii Europejskiej, Pracownia Badań nad Mniejszościami Narodowymi i Etnicznymi - Instytut Politologii - Uniwersytet Zielonogórski, Zielona Góra.

Palko V. (2010), Chore hviezdy krest'ansko-demokraticke, Impulz 1, http://www. impulzrevue.sk/article.php?531. 
Pera M. (2008), Perché dobbiamo dirci cristiani. Il liberalismo, l'Europa, l'etica, Mondadori, Milano.

Pew Research Center(2016), Thefuture ofworld religions, http://www.globalreligiousfutures. org.

Pew Research Center (2017), Europe’s Growing Muslim Population, https://www.pewforum. org/2017/11/29/europes-growing-muslim-population/.

Plato (1994), Gorgias, Agora Publications, Millis.

Regulation (EU) 2016/679 of the European Parliament and of the Council of 27 April 2016 on the protection of natural persons with regard to the processing of personal data and on the free movement of such data, 2016, https://eur-lex.europa.eu/legal-content/ EN/TXT/?uri=CELEX\%3A32016R0679.

Service-Public (2019), https://lannuaire.service-public.fr/gouvernement/administration -centrale-ou-ministere_185251.

Spaemann R. (2015), “The Undying Rumor: The God Question and the Modern Delusion” in: A Robert Spaemann Reader: Philosophical Essays on Nature, God \& the Human Person, Oxford University Press, Oxford.

Tocqueville A. de (2002), Democracy in America, Pennsylvania State University, Pennsylvania.

Weber M. (1994), “The Profession and Vocation of Politics”, in: Political Writings, Cambridge University Press, Cambridge. 